\section{International Scientific Journal Theoretical \& Applied Science}

\author{
p-ISSN: 2308-4944 (print) e-ISSN: 2409-0085 (online) \\ Year: $2016 \quad$ Issue: 1 Volume: 33 \\ Published: $30.01 .2016 \quad$ http://T-Science.org
}

Alexei Grigoryevich Burda
$\mathrm{PhD}$, Head of the Department of Economic
Cybernetics of the Kuban State Agrarian University, Krasnodar, Russian Federation agburda@mail.ru

SECTION 21. Pedagogy. Psychology. Innovation in Education.

\title{
INNOVATIONS IN TRAINING OF THE TOP SKILLS: INFORMATION SUPPORT OF TEACHING BASES OF RESEARCH ACTIVITY TO GRADUATE STUDENTS-ECONOMISTS
}

\begin{abstract}
In article innovative approaches to teaching discipline "Basics of research activity» to the graduate students who are trained in the Economy direction when training the top skills in postgraduate study are covered features of carrying out lecture occupations and occupations of seminar type, the organization of independent work according to new requirements are reflected.

Key words: innovation, innovative approach, scientific activities, research, postgraduate, personnel, higher qualifications, the economy, the educational process, scientometrics, information support.

Language: English

Citation: Burda AG (2016) INNOVATIONS IN TRAINING OF THE TOP SKILLS: INFORMATION SUPPORT OF TEACHING BASES OF RESEARCH ACTIVITY TO GRADUATE STUDENTS-ECONOMISTS. ISJ Theoretical \& Applied Science, 01 (33): 22-25.

Soi: http://s-o-i.org/1.1/TAS-01-33-5 Doi: crossef http://dx.doi.org/10.15863/TAS.2016.01.33.5
\end{abstract}

The relevance of generalization of experience of the educational process in graduate school due to the fact that the training of highly qualified personnel by the Federal Law "On Education in the Russian Federation" is considered as the level of higher education that advances the development and implementation of training programs of the teaching staff in graduate school in the list of priorities higher education and the formation of an innovative society [3].

The purpose of the study - summarize the experience of the application of innovative approaches and perspectives of information support of teaching the basics of research activities in the preparation of highly qualified personnel in graduate school in the development of information and the formation of an innovative society.

In the Kuban State Agrarian University Department of Economic Cybernetics teaches discipline "Fundamentals of research activities" graduate students on seven areas of training. The article used the monographic method of describing the training of highly qualified personnel in the direction of "Economy", which focused the largest contingent of graduate students, six profiles (direction) in the framework of ongoing educational programs: "Economics and National Economy Management", "Accounting and Statistics", "Finance and Credit", "The world economy", "Economic Theory", "Mathematical and instrumental methods of economics". In accordance with the competencies defined by the educational standards and curricula for each profile (orientation) developed work programs of discipline "Fundamentals of research activities" and the foundations of assessment tools.

The necessity and appropriateness of teaching the basics of research and development economists in graduate obvious and caused by such professional activities, certain educational standard as research activities in the field of economics and teaching activities: conducting scientific research in the educational organization.

Topics of lectures include such important moments as the young researchers:

the value and nature of scientific research, scientific research;

development of scientific research in Russia and abroad, including the development of science in different countries, methodological basis for determining the level of science in different countries, the existing indices and ratings in this area (rating countries in terms of research activity index level of education in the countries world adult literacy index, index of aggregate share of students in primary, secondary and higher education, rating the 
best universities in the world ranking of universities in Russia, including the level of research activity); the organization of science in the Russian Federation, the statistics of the number of organizations engaged in research and development, the number of researchers, the age distribution of researchers in the domestic science in different years; Main indicators of postgraduate study: the number of organizations that train graduate students the number of graduate students, admission to graduate school, graduation from graduate school, including the defense of a thesis, the number of graduate students in the subject of the Russian Federation and in separate branches of science;

methodology and methods of scientific research, including consideration of the nature of the research methodology, the principles and problems of research, development of hypotheses and concept studies, procedural and methodological schemes and scientific knowledge in the research;

basic methods of finding information for scientific research, including consideration of the documentary sources of information, organization of reference and information activities, methods of work with directories and files, including electronic catalogs of libraries, resources and services Scientific Electronic Library, the Russian State Library, electronic library systems;

methods of working on the manuscript of scientific research, particularly the preparation and presentation of the dissertation, including the composition of scientific works, receptions scientific writing, the manuscript, the language and style of scientific work, the consideration of the history of development of the dissertation as a qualifying research, procedures for the preparation, presentation and defense of a thesis.

Prepared lecture notes, methodological developments for training and seminary-type benefits for independent work of students placed on the cathedral site in the village of "Documents" section on the educational portal of the University (http: //edu.kubsau.local). Multimedia presentations of lectures delivered in 2015-2016 academic year, and will be located on the educational portal. The organization of educational process on the basis of scientific-research activities are widely used information technology and is available at the Department of Economic Cybernetics, Kuban State Agrarian University experience of their use in research [1], [11] and education [2], [9], [10].

Classes such as seminary graduate students are invited in relation to the subject of his research, his final qualifying works, which tend to be based future $\mathrm{PhD}$ thesis, to justify the urgency, aim to formulate and define the research problem, its subject and object, to formulate a working hypothesis. In recognition of the students, the implementation of this task is useful not only for understanding the key points of the methodological apparatus of scientific research, but also of practical interest in preparing for the future introduction of the final qualifying work and the introductory part of the report to protect it.

Carrying out a literature search on the subject of his scientific work using materials Scientific Electronic Library (http://e.library.ru), the national digital resource Rukont - interdisciplinary digital library (http://rucont.ru), electronic library system IPR books (http://www.iprbookshop.ru), e-library system of the publishing house "Lan»" (http://lanbook.com/ebs), the Russian State Library (http://rsb.ru), electronic catalog of scientific and technical literature Russian Institute for Scientific and Technical Information of Russian Academy of Sciences, the educational portal KubSAU (http: //edu.kubsau.local), electronic library catalog KubGAU, students make a list of bibliographic records found literature indicating the availability of the source.

Studying the list of remote network resources of the Russian State Library (www.rsb.ru/ru/networkresource) is accompanied by definition, those that may be useful during a specific individual research. Of particular interest to graduate students is a network share of the Russian State Library "Theses: foreign collection in the public domain» (www.rsb.ru/ru/root34893492/diss). Using one of the presented projects, for example, DARTEurope, students are trying to find the thesis of foreign scholars on the subject close to his research. In this interdisciplinary relationship of a foreign language graduate students learn in practice, and when there are difficulties with the translation services use the Internet for online-translation. Foreign Language thus acts as a source of social and cultural formation of the individual graduate students and expand the horizons of students [6].

By studying the procedure for depositing theses (projects) prepared for the defense of dissertations and theses, as well as results of intellectual activities (unpublished works) in the Russian State Library, students are asked to answer the questions: "What are the goals deposition of different types of work? In what ways can use to provide the author of the work and a set of documents to the Russian State Library? Is there a fee for this service? What document is issued and what is the cost Escrow unpublished works by the Russian State Library? ".

In the study of discipline students learn the formulation of the problem of measurement of quantitative characteristics of scientific information, history and main directions of scientometrics, framework for the assessment and funding of various research units (institutes, teams, individuals), the problem of the use of scientometric assessments, citation index, Hirsch, online projects Web of Science, Scopus, Web of Knowledge, Russian Science Citation Index. Using materials 
http://elibrary.ru, graduate define index Hirsch said the teacher research organizations and universities in Krasnodar, carried out a comparative analysis of the publication activity of universities, colleges build rating of Krasnodar region in the number of foreign publications, the number of publications in international journals and of the Russian WAC list, according to the number of authors who have published in journals included in Web of Science or Scopus, define index Hirsch said the teacher of the author, shall seek a list of articles that refer to the work of the author of this teacher, the percentage of self-citations. In carrying out these tasks take into account the experience of the analysis of the scientific activity of university professors in some regions [7] conceptualized views of reputable scientists about the negative consequences of illconsidered active implementation of scientometric approaches [5], approaches reputable scientists and experts in the organization of information support systems in various fields, including education [4], [8], [9].

Education graduate economists on the subject "Fundamentals of research activities" carried out by full-time and correspondence. Postgraduates Absentee Carry out work on individual options. Tasks for quiz issued for orientation sessions are posted on the Internet at the cathedral page and include theoretical questions on the methodology of research and practical tasks for the development of methods and procedures to find information for research using electronic library systems and directories, definition of publication activity of scientific organizations and scientists, the use of modern Internet services to participate in scientific conferences, publication of articles in journals, including the application procedure, sending a text article, acquaintance with published materials and preparation of bibliographic description.

Since the design of articles, pamphlets and monographs scientist has to comply with the requirements of magazines and publishers to comply with the level of originality of scientific texts, postgraduate students with a special interest related to practical tasks in this field, and the discussion of the results has been very lively and emotionally.

At the final session in the mode of active communication business professional interactively train and master teacher, including communication via a computer network in real time, investigated the main challenges and trends research. Summarizing the progress made in the course of development of the discipline of the main results of the classroom and the resulting individual, independent and research work of students on the basic provisions of the foundations of scientific research.

It seems promising graduate students to familiarize with the possibilities of bibliographic managers, as well as automated work with the bibliography in modern text editors

The accumulated experience of innovative approaches to the organization and implementation of educational process on discipline "Fundamentals of research activities" in the postgraduate of the Kuban State Agrarian University in the direction of "Economy", in our opinion, may be interesting and useful to our colleagues in educational institutions offering training higher qualification.

\section{References:}

1. Burda AG (2012) Informacionnye tehnologii i model'nye trenazhery $\mathrm{v}$ obuchenii metodam optimal'nyh reshenij $\mathrm{v}$ agrojekonomicheskih sistemah: monografija / AG Burda, GP Burda, SN Kosnikov, SV Permjakova, VV Osennij, OJu Francisko. - Krasnodar: KubSAU, 2012. $133 \mathrm{p}$.

2. Burda GP (2005) Modelirovanie jekonomiki: ucheb. posobie dlja vuzov. Chast' II. Metody modelirovanija proizvodstva i rynka / GP Burda, AG Burda, AnG Burda. - Krasnodar: KubSAU, 2005. - 545 p.

3. Zelinskaja MV (2015) Ot investicij v obrazovanie $\mathrm{k}$ innovacionnomu obshhestvu / M. V. Zelinskaja, Ju. V. Sidak //
Mezhdunarodnaja nauchno-prakticheskaja konferencija po aktual'nym voprosam jekonomiki i gumanitarnyh nauk v $2015 \mathrm{~g}$. Materialy nauchno-prakticheskoj konferencii. Krasnodar: Krasnodarskij centr nauchnotehnicheskoj informacii, 2015. - pp. 110-114.

4. Kurnosov AP (2011) Jekonomikomatematicheskoe modelirovanie $\mathrm{v}$ sisteme informacionnogo obespechenija dejatel'nosti hozjajstvujushhih sub\#ektov agrarnoj sfery / AP Kurnosov, AV Ulez'ko // Modelirovanie i informacionnoe obespechenie jekonomicheskih processov $\mathrm{V}$ APK : Sb. nauch. trudov. Voronezh : FGOU VPO Voronezhskij GAU, 2011. - pp. 3-20. 


\begin{tabular}{|c|c|c|c|c|c|c|}
\hline Impact Factor: & $\begin{array}{l}\text { ISRA (India) } \\
\text { ISI (Dubai, UAE } \\
\text { GIF (Australia) } \\
\text { JIF }\end{array}$ & $\begin{array}{l}=1.344 \\
=0.829 \\
=0.564 \\
=1.500\end{array}$ & $\begin{array}{l}\text { SIS (USA) } \\
\text { PИНЦ (Russia) } \\
\text { ESJI (KZ) } \\
\text { SJIF (Morocco) }\end{array}$ & $\begin{array}{l}=0.912 \\
=0.179 \\
=1.042 \\
=2.031\end{array}$ & $\begin{array}{l}\text { ICV (Poland) } \\
\text { PIF (India) }\end{array}$ & $\begin{array}{l}=6.630 \\
=1.940\end{array}$ \\
\hline
\end{tabular}

5. Lucenko EV (2015) Hirshamanija pri ocenke rezul'tatov nauchnoj dejatel'nosti, ee negativnye posledstvija i popytka ih preodolenija $\mathrm{s}$ primeneniem mnogokriterial'nogo podhoda i teorii informacii / EV Lucenko // Politematicheskij setevoj jelektronnyj nauchnyj zhurnal Kubanskogo gosudarstvennogo agrarnogo universiteta. - 2015. - № 108. - pp. 1-29.

6. Prosvirnina LG (2015) Inostrannyj jazyk kak istochnik formirovanija sociokul'turnoj lichnosti i rasshirenija krugozora uchashhihsja / LG Prosvirnina, AV Ulanov // Social'nojekonomicheskie i pravovye sistemy: sovremennoe videnie. Materialy Mezhdunarodnoj nauchno-prakticheskoj konferencii. - 2015. - pp. 156-158.

7. Puzina NV (2014) Analiz nauchnoj aktivnosti prepodavatelej omskih vuzov / NV Puzina // Vestnik Sibirskogo instituta biznesa i informacionnyh tehnologij. - 2014. - № 2 (10). - pp. 99-104.

8. Ulez'ko AV (2013) Informacionnoe obespechenie upravlenija APK Lipeckoj oblasti i osnovnye napravlenija ego razvitija / AV Ulez'ko, MI Suhomlinova, VN Dushkin // Regional'naja innovacionnaja sistema: sostojanie, problemy, napravlenija formirovanija. Sb. nauch. trudov po itogam nauchno-prakticheskoj konferencii po problemam razvitija innovacionnoj dejatel'nosti v Lipeckoj oblasti. - Elec, 2013. - pp. 174-186.

9. Zatonskaja IV (2015) Jekonomikomatematicheskie metody $\mathrm{v}$ optimiza-cii struktury agrarnogo predprijatija // Teoreticheskie i prakticheskie as-pekty razvitija sovremennoj nauki. Materialy XV mezhdunarodnoj nauchno-prakticheskoj konferencii. Nauchno-informacionnyj izdatel'skij centr "Institut strategicheskih issledovanij". 2015. pp. 78-83.

10. Burda GP (2012) Praktikum po metodam optimal'nyh reshenij: ucheb. posobie dlja vuzov / GP Burda, AG Burda - Krasnodar: KubGAU, 2012. $-233 \mathrm{p}$.

11. Trubilin AI (2012) Parametrizacija, modelirovanie i optimizacija konkurentosposobnogo APK: monografija / AI Trubilin, AG Burda, GP Burda, IM Blagivskij, SN Kosnikov, VV Kochetov, EA Metel'skaja, SI Turlij, OJu Francisko; pod rukovodstvom i red. akademika RASHN, doktora jekonomicheskih nauk, professora IT Trubilina - Krasnodar : KubGAU, 2012. - 630 p. 